\title{
PELATIHAN PEMBUATAN MEDIA VIDEO MENGGUNAKAN POWER POINT BAGI GURU SMA NEGERI I GALESONG
}

\author{
Husain $\mathrm{AS}^{1}$, Khaidarsyah ${ }^{2}$ \\ ${ }^{1,2)}$ STKIP -PI MAKASSAR \\ e-mail: husainaspale@gmail.com
}

\begin{abstract}
Abstrak
Pelatihan Animasi 2 Dimensi untuk Membuat Media Pembelajaran Interaktif dengan Program Powerpoint bagi Guru-Guru SMA Negeri 1 Galesong ini bertujuan untuk meningkatkan kualitas pembelajaran, agar guru mendapat tambahan wawasan ilmu pengetahuan tentang pembuatan media pembelajaran multimedia yang interaktif dan atraktif menggunakan program Powerpoint. Metode yang diterapkan dalam kegiatan ini adalah Metode Presentasi mengenai Pengantar materi tentang animasi 2 dimensi dengan powerpoint sebagai media pembelajaran. Kegiatan dilanjutkan dengan praktik pembuatan media pembelajaran dengan animasi 2 dimensi program powerpoint. Kegiatan dilanjutkan dengan evaluasi. Pelaksanaan PKM diawali dengan penyampaian materi tentang powerpoint dan pemanfaatan fasilitas pada program tersebut untuk membuat animasi 2 dimensi sederhana. Kegiatan dilanjutkan dengan praktik pembuatan media pembelajaran dengan penerapan animasi 2 dimensi menggunakan program powerpoint. Hasil kegiatan PKM ini berupa bahan ajar dengan media powerpoint yang mengaplikasikan animasi 2 dimensi.
\end{abstract}

Kata Kunci : Pelatihan animasi 2 dimensi, guru SMA 1 Galesong

\begin{abstract}
2 Dimension Animation Training to Create Interactive Learning Media with Powerpoint Program for Galesong 1 High School Teachers aims to establish cooperation with stakeholders in improving the quality of learning and so that teachers get additional scientific insights about making interactive and attractive multimedia learning media using the Powerpoint program. The method applied in this activity is the Presentation Method about the introduction of material about 2-dimensional animation with PowerPoint as a learning medium. The activity continued with the practice of making instructional media with 2-dimensional animation of the PowerPoint program. The activity continued with evaluation. The implementation of PKM begins with the delivery of material about powerpoints and the use of facilities in the program to create simple 2-dimensional animations. The activity continued with the practice of making learning media with the application of 2-dimensional animation using the PowerPoint program. The results of this PKM activity in the form of teaching materials with powerpoint media that applies 2dimensional animation.
\end{abstract}

Keywords : 2-dimensional animation training, 1 Galesong high school teacher

\section{PENDAHULUAN}

Sejak beberapa tahun belakangan ini teknologi informasi dan komunikasi telah banyak digunakan dalam proses belajar mengajar, dengan satu tujuan mutu pendidikan akan selangkah lebih maju seiring dengan kemajuan teknologi. Perkembangan teknologi multimedia telah menjanjikan potensi besar dalam merubah cara seseorang untuk belajar, untuk memperoleh informasi, menyesuaikan informasi dan sebagainnya.

Sistem pendidikan dewasa ini telah mengalami kemajuan yang sangat pesat. Berbagai cara telah dikenalkan serta digunakan dalam proses belajar mengajar (PBM) dengan harapan pengajaran guru akan lebih berkesan dan pembelajaran bagi murid akan lebih bermakna. 
Multimedia juga menyediakan peluang bagi pendidik untuk mengembangkan teknik pembelajaran sehingga menghasilkan hasil yang maksimal. Demikian juga bagi pelajar, dengan multimedia diharapkan mereka akan lebih mudah untuk menentukan dengan apa dan bagaimana siswa untuk dapat menyerap informasi secara cepat dan efisien.

Sampai saat ini media pembelajaran interaktif belum berkembang dengan optimal di Indonesia. Salah satu kendala pengembangan media pembelajaran interaktif adalah kurang dikuasainya teknologi pengembangan media interaktif oleh para pengajar, sehingga pengembangan materi pembelajaran interaktif dengan komputer kurang optimal.

Pembuatan media pembelajaran interaktif akan menggunakan piranti lunak presentasi Microsoft Powerpoint, sebuah piranti lunak yang memberikan banyak sekali manfaat bagi pembelajaran. Dua keuntungan pokok dari piranti lunak ini adalah karena piranti ini tersedia di semua komputer berprogram Microsoft Office, dan dapat dikembangkan oleh orang yang buta program komputer.

Meskipun piranti lunak ini mudah dan sederhana namun dapat memberikan manfaat yang besar bagi pembelajaran . Piranti lunak ini dapat menampilkan teks, gambar, suara, dan video. Dengan demikian, piranti lunak ini bisa mengakomodasi semua kegiatan pembelajaran interaktif seperti mendengarkan, membaca, menulis dan juga bermain visual games. Tampilan yang dihasilkan dari piranti lunak ini bisa semenarik program yang dibangun dengan piranti lunak yang canggih.

Sajian audio visual atau lebih dikenal dengan sebutan multimedia menjadikan visualisasi lebih menarik. Pembelajaran dengan mengembangkan media pembelajaran multimedia seperti ini dapat menyajikan sebuah tampilan berupa teks nonsekuensial, nonlinear, dan multidimensional dengan percabangan tautan dan simpul secara interaktif. Tampilan tersebut akan membuat pengguna (user) lebih leluasa memilih, mensintesa, dan mengelaborasi pengetahuan yang ingin dipahaminya.

Proses belajar mengajar (PBM) di sekolah seringkali dihadapkan pada materi yang abstrak dan di luar pengalaman siswa sehari-hari, sehingga materi ini menjadi sulit diajarkan guru dan sulit dipahami siswa. Visualisasi adalah salah satu cara yang dapat dilakukan untuk mengkonkritkan sesuatu yang abstrak. Gambar dua dimensi atau model tiga dimensi adalah visualisasi yang sering dilakukan dalam PBM. Pada era informatika visualisasi berkembang dalam bentuk gambar bergerak (animasi) yang dapat ditambahkan suara (audio).

Berdasar berbagai kondisi tersebut, kegiatan pelatihan ini sangat penting untuk diadakan. Pelatihan pengembangan media pembelajaran multimedia dengan pemanfaatan program Powerpoint yang akan dikembangkan dan diterapkan bagi para guru SMA ini diharapkan akan memberikan wawasan baru dalam pembuatan media pembelajaran, mengingat kemampuan program ini dalam hal pembuatan animasi untuk media pembelajaran multimedia yang menarik dengan cara yang relatif mudah. Dengan dikuasainya media pembelajaran multimedia oleh para guru SMA diharapkan akan pemicu minat siswa untuk lebih bersemangat dalam mengikuti pelajaran, dan pada akhirnya akan meningkatkan kualitas pembelajaran secara keseluruhan.

Powerpoint pada pelatihan ini bukan sekedar pengantar powerpoint, akan tetapi lebih pada pengembangan animasi 2 dimensi sebagai salah satu fitur yang ada pada program power point sendiri yang masih jarang digunakan secara maksimal dalam pembuatan media pembelajaran.

Sekolah yang menjadi sasaran kegiatan kali ini adalah SMA Negeri 1 Galesong yang telah memiliki laboratorium komputer yang lengkap, sehingga dapat diasumsikan bahwa penggunaan komputer dalam proses belajar mengajar sudah sangat familiar. Disamping itu yang menjadi pertimbangan lain adalah pihak guru-guru SMA Negeri 1 Galesong mengajukan permohonan agar dilatih untuk membuat media pembelajaran interaktif dengan pemanfaatan program Powerpoint, sehingga pelatihan yang akan diadakan ini benar-benar sesuai dengan kebutuhan sekolah yang menjadi sasaran pengabdian. 


\section{METODE}

Metode yang akan diterapkan dalam kegiatan ini adalah pelatihan dan praktek langsung. Dalam pelatihan ini akan diberikan beberapa kegiatan yang meliputi penyajian materi, dan praktik pembuatan media oleh para guru peserta pelatihan. Selanjutnya media pembelajaran yang telah dikerjakan oleh para guru akan dikompetisikan antar peserta dan yang terbaik akan mendapatkan penghargaan dari tim pengabdi.

\section{KHALAYAK SASARAN PkM}

Sasaran dalam pengambdian ini adalah guru-guru yang aktif mengajar di SMA Negeri 1 Galesong. Pada awal kegiatan tim hanya mengharap keikutsertaan 25 guru sebagai peserta dikarenakan keterbatasan tim PkM dari segi sumber daya manusia dan dana. Akan tetapi pada saat pelaksanaan berlangsung, jumlah peserta melebihi rencana karena antusias guru untuk mengikuti kegiatan tersebut.

2. METODE KEGIATAN PkM

Metode yang digunakan dalam kegiatan ini adalah pelatihan dan praktrk langsung ke lokasi. Dalam pelatihan ini akan diberikan beberapa kegiatan yang meliputi penyajian materi, praktik perancangan interior, dan simulasi penataan interior secara langsung di sekolah.

\section{LANGKAH-LANGKAH KEGIATAN PKM}

Adapun beberapa langkah yang ditempuh dalam kegiatan PkM kali ini mencakup beberapa tahap berikut ini.

\section{a. Persiapan}

Tahap persiapan merupakan tahap awal sebelum pelaksanaan PkM. Dalam tahap ini ada beberapa hal yang dilakukan.

b. Koordinasi Internal, dilakukan oleh Tim untuk merencanakan pelaksanaan secara konseptual, operasional, serta job description.

c. Penentuan dan rekruitment peserta pelatihan.

d. Pembuatan Instrumen PKM, seperti lembar presensi, angket, lembar kerja, dsb.

e. Persiapan konsumsi, publikasi, lokasi, dokumentasi, dsb.

f. Pelaksanaan Pelatihan

Tahap ini merupakan tahap pelatihan yang diberikan kepada para guru di SMA Negeri 1 Galesong, jumlah peserta 35 guru dan kegiatan dilaksanakan di ruang Laboratorium fisika dikarenakan jumlah peserta yang sangat banyak dan Lab Komputer tidak memadahi. Pelaksanaan kegiatan menggunakan perangkat computer berupa laptop dan netbook milik masing-masing peserta.

\section{g. Persiapan}

Tahap persiapan merupakan tahap awal sebelum pelaksanaan PKM. Dalam tahap ini ada beberapa hal yang dilakukan.

a. Koordinasi Internal, dilakukan oleh Tim untuk merencanakan pelaksanaan secara konseptual, operasional, serta job description masing-masing anggota.

b. Penentuan dan rekruitment peserta pelatihan.

c. Pembuatan Instrumen PKM, seperti lembar presensi, angket, lembar kerja.

d. Persiapan konsumsi, publikasi, lokasi, dokumentasi, dsb.

h. Pelaksanaan Pelatihan

Tahap ini merupakan tahap pelatihan yang diberikan kepada para guru SMA Negeri 1 Galesong. Pelaksanaan pelatihan ini mencakup beberapa hal berikut.

a. Penyajian Materi

Sebelum penyajian materi, kegiatan diawali dengan penugasan persiapan berupa RPP masingmasing peserta dan pemilihan materi pelajaran yang akan digunakan sebagai hasil praktek guru pada pelatihan tersebut. Selanjutnya kegiatan diikuti dengan pemberian materi powerpoint animasi oleh tim. 
Materi yang disajikan terkait dengan pengenalan dan penggunaan program Powerpoint untuk pembuatan media pembelajaran. Penyajian berikutnya adalah pemanfaatan powerpoint untuk pembuatan animasi 2 dimensi untuk membantu guru dalam membuat media lebih baik dan atraktif. Penyajian ini diploting dalam 1 hari tatap muka. Penyaji materi adalah tim pengabdi sendiri disesuaikan dengan bidang keahlian masing-masing.

b. Penugasan Praktik

Pada akhir materi peserta akan diberi tugas praktik sesuai materi yang telah disajikan untuk menggali penyerapan dan pemahaman materi serta melihat kreativitasnya dalam berkarya. Dalam pelatihan ini para guru ditugaskan untuk membuat satu media pembelajaran terkait mata pelajaran dan materi yang diampu masing-masing guru. Tim pengabdi mendampingi, memandu dan mengarahkan serta memberikan solusi apabila timbul permasalahan selama penugasan praktik.

c. Pemilihan Karya Media Pembelajaran Terbaik

Pada akhir pelatihan, media yang telah dibuat oleh para guru akan dikumpulkan dan dinilai oleh tim pengabdi dan karya terbaik akan diberikan penghargaan dari tim pengabdi.

d. Refleksi dan Penutupan Program PKM

Di akhir kegiatan tim PKM memberikan penugasan untuk dilanjutkan di rumah dikarenakan waktu yang tidak memungkinkan untuk dilanjutkan di dalam kelas, sedangkan guru masih antusias untuk mendapat bimbingan secara personal. Namun kegiatan refleksi tetap dilaksanakan dengan menampilkan karya guru yang telah membuat hasil karya animasi 2 dimensi sebagai media pembelajaran.

Setelah semua kegiatan yang telah direncanakan terlaksana, ketua tim PkM menutup program dan memberikan penghargaan kepada segenap peserta pelatihan untuk menerapkan apa yang telah didapatkan untuk memperbaiki media pembelajaran masing-masing. Diharapkan pada PkM yang akan akan datang program ini dapat dilanjutkan lagi dan dapat lebih menjangkau jumlah sekolah lain tak hanya di SMA Negeri 1 Pleret saja, sehingga kebermanfaatan program ini dapat dirasakan oleh sekolah yang lebih banyak.

1. Evaluasi Kegiatan

Evaluasi kegiatan PkM ini dilakukan dengan beberapa cara. Evaluasi hasil dilihat dari tugas praktik para peserta yang ada. Hasil praktiknya dinilai dan hal itu menggambarkan keberhasilan materi yang telah disajikan. Selain itu, secara proses juga dicermati kinerja dan kesertaan para peserta. Di akhir kegiatan Tim menjaring data kebermaknaan program pada para peserta.

\section{FAKTOR PENDUKUNG DAN PENGHAMBAT}

Kegiatan ini dapat berlangsung dengan lancar berkat adanya beberapa faktor pendukung kesuksesan kegiatan dari luar maupun dari dalam. Pendukung dari dalam yakni dari tim pelaksana sendiri, dan dari luar adalah dari pihak peserta. Akan tetapi disamping itu tetap terdapat faktor penghambat yang sedikit menghalangi kelancaran kegiatan, meskipun semua itu telah dapat diselesaikan dengan baik. Berikut faktor pendukung dan penghambat kegiatan ini.

1. Faktor Pendukung

Kegiatan Pengabdian pada Masyarakat ini telah terlaksana dengan baik berkat dukungan berbagai faktor yaitu:

a. Komunikasi dan koordinasi tim

Komunikasi antar anggota tim berlangsung lancar dan efektif sehingga koordinasi tim pada proses persiapan, pembagian tugas, pelatihan dan simulasi dapat berlangsung dengan baik dan tepat waktu.

b. Komitmen peserta pelatihan

Peserta pelatihan yang terdiri dari guru-guru di SMA N 1 Galesong sangat antusias dan bersemangat dalam mengikuti pelatihan dari awal hingga akhir. Begitu pula saat penugasan dimana guruguru tersebut diminta untuk membuat media dengan animasi power point sangat bersemangat. 
2. Faktor Penghambat

a. Keterbatasan Waktu

Waktu yang singkat karena pelaksanaan kegiatan PkM dilangsungkan pada jam setelah usai pembelajaran dan hari Sabtu membuat kegiatan tidak berjalan sangat optimal, ada beberapa peserta yang meninggalkan pelatihan karena urusan lain.

b. Keterbatasan Dana

Biaya yang terbatas membuat tim harus berusaha mengoptimalkan dana yang ada, terlebih lagi jumlah peserta yang terlampau banyak karena keinginan untuk ikut serta dalam kegiatan pelatihan.

\section{HASIL DAN PEMBAHASAN}

Pada bagian ini akan dipaparkan beberapa hal yang terkait dengan pelaksanaan program. Hal itu meliputi hasil yang dicapai dan pembahasan pelaksanaan PkM tahun ini.

\section{A. HASIL PELAKSANAAN KEGIATAN PKM}

Guru merupakan salah satu yang menggerakkan pendidikan di Indonesia. Namun, tanpa wawasan yang selalu dikembangkan dan di-up grade maka guru akan makin ketinggalan di era sekarang. Apalagi kebutuhan siswa juga makin berkembang. Oleh sebab itu guru harus mengikuti perkembangan kemajuan teknologi dan informasi agar memiliki kedekatan dengan siswa. Kemenarikan media pembelajaran sangat mempengaruhi proses belajar mengajar sendiri.

Pelatihan ini memberikan beberapa materi yang terkait dengan upaya mengembangkan media pembelajaran interaktif dengan pemanfaatan program powerpoint untuk membuat animasi 2 dimensi agar pembelajaran yang diberikan oleh guru menjadi lebih atraktif sehingga meningkatkan minat dan kualitas belajar siswa. Materi yang disajikan oleh pengabdi dapat diterima, dicerna, dan dipahami peserta dengan baik. Jumlah peserta yang sebanding dengan jumlah pengabdi yang berperan sebagai instruktur dan tutor menjadikan pelatihan ini menjadi lebih kondusif. Hal ini didukung pula dengan kemampuan peserta di bidang computer telah cukup memadai karena pada proses perekrutan telah ditetapkan standar minimal peserta harus telah menguasai computer dasar sehingga pelatihan dapat berjalan lancar dan para peserta dapat berkomunikasi dengan para pembicara dan peserta lain dengan lebih baik.

Materi yang tersajikan sebanyak 4 (empat) bahasan yang masing-masing disajikan oleh anggota Tim Pengabdi sesuai bidang yang bersangkutan. Berikut tabel daftar materi dan pematerinya yang telah terlaksana dalam program PkM ini.

Pelaksanaan program ini melibatkan 2 mahasiswa agar kegiatan dapat berjalan lancar. Kegiatan tanya jawab dilakukan bersamaan dengan penyajian materi. Para peserta dapat langsung berdiskusi dengan para pemateri secara langsung untuk memahamkan materi dan sharing pengalaman terkait dengan masalah yang tengah dibahas dalam materi bersangkutan. Kegiatan ini terlaksana di ruang laboratorium fisika di SMA Negeri 1 Galesong dengan diikuti oleh 35 peserta. Berikut daftar peserta pelatihan.

\section{PEMBAHASAN HASIL PELAKSANAAN PKM}

Guru merupakan salah satu yang menggerakkan pendidikan di Indonesia. Namun, tanpa wawasan yang selalu dikembangkan dan di-up grade maka guru akan makin ketinggalan di era sekarang. Kebutuhan siswa dalam belajar saat ini harus didukung dengan perkembangan teknologi informasi yang memadahi agar tidak ada jurang pemisah antara guru dan siswa. Guru semestinya membuka diri untuk belajar teknologi informasi untuk menjembatani pembelajaran dengan siswa agar pembelajaran memiliki kemenarikan dalam tampilan maupun kejelasan dalam penyampaian materi.

Pelatihan ini memberikan beberapa materi yang terkait dengan upaya pemanfaatan teknologi informasi yang telah tersedia dengan optimal. Media pembelajaran sebagai salah satu jembatan transfer ilmu kepada siswa semestinya menjadi alat jitu untuk menjelaskan materi. Oleh sebab itu pelatihan ini diharapkan dapat mengoptimalkan kemampuan guru dalam memanfaatkan program powerpoint sebagai media pembelajaran dengan aplikasi animasi 2 dimensi. 
Pada tahap persiapan, tim PkM telah mempertimbangkan banyak hal antara lain ketersediaan sarana dan prasarana di SMA Negeri 1 Galesong dalam ketersediaan perangkat computer. Laboratorium computer telah tersedia di sekolah dan di beberapa kelas telah tersedia LCD Proyektor yang dapat dimanfaatkan oleh guru sebagai media pembelajaran. Untuk itu pemanfaatan powerpoint sebagai media pembelajaran di SMA 1 Galesong tidak menjadi hal yang asing

1) Berdasarkan diskusi yang dilaksanakan setelah pemaparan materi, dapat dilihat bahwa para guru dapat memahami pentingnya pemanfaatan powerpoint dalam menunjang media pembelajaran. Selanjutnya berdasar hasil praktik juga dapat dilihat bahwa para guru mampu:

Mengidentifikasi materi pembelajaran yang dapat memanfaatkan program animasi 2 dimensi powerpoint untuk media pembelajaran.

2) Guru antusias dengan program yang dikenalkan karena sifatnya rekreatif dan membantu kejelasan materi pembelajaran.

3) Membuat media pembelajaran dengan memanfaatkan program powerpoint dengan animasi 2 dimensi.

\section{SIMPULAN}

Berdasar hasil pelaksanaan kegiatan pengabdian kepada masyarakat ini dan uraian pembahasan di atas, dapat disimpulkan beberapa hal sebagai berikut ini.

1. Pelatihan ini memberikan beberapa materi yang terkait dengan pembuatan media pembelajaran dengan memanfaatkan program powerpoint.

2. Materi yang disajikan dapat diterima, dicerna, dan dipahami peserta dengan baik. Jumlah peserta yang tidak terlalu banyak menjadikan pelatihan ini menjadi lebih kondusif.

3. Kegiatan berlangsung lancar, tepat waktu dan sesuai dengan yang diharapkan dan para peserta dapat berkomunikasi dengan para pembicara dan peserta lain dengan baik.

\section{SARAN}

Program pelatihan ini sangat bermanfaat dalam upaya meningkatkan kemampuan guru dalam berinovasi membuat media pembelajaran yang menarik dan memudahkan siswa dalam memahami materi pembelajaran. Untuk itu beberapa saran dapat disampaikan sebagai berikut:

1. Sebaiknya program pelatihan yang bertujuan untuk meningkatkan kemampuan guru dalam pembuatan media pembelajaran senantiasa dilaksanakan.

2. Hendaknya program ini dapat terus berlanjut sehingga lebih banyak lagi sekolah yang dapat merasakan manfaatnya.

3. Para guru peserta pelatihan diharapkan dapat ikut aktif berperan dalam meningkatkan kualitas bahan ajar masing-masing.

\section{DAFTAR PUSTAKA}

Idris, Nuny S. 1999. Ragam Media Dalam Pembelajaran. A Paper presented at KIPBIPA III, Bandung. Anderson, Ronald A. 1994. Pemilihan dan Pengembangan Media untuk Pembelajaran, terjemahan oleh Yusufhadi Miarso, dkk. Jakarta: PT. Raja Grafindo Persada.

Juhaeri. 2009. Pengantar Multimedia Untuk Media Pembelajaran -bagian 2-Published: July 10, 2009 • dari http://tutorial.babastudio.com/

Miarso, Yusufhadi. 2004. Menyemai Benih Teknologi Pendidikan. Jakarta: Prenada Media.

Purnomo. 1996. Strategi Pengajaran. Yogyakarta: Universitas Sanata Dharma. 